\author{
박판주조공정으로 제조한 $\mathrm{Al}-8.0 \mathrm{Zn}-2.5 \mathrm{Mg}-2.0 \mathrm{Cu}$ 합금 판재의 \\ 소부경화특성에 미치는 예비시효의 영향 \\ 허지구 ${ }^{1,2}$ - 이윤수 1 - 김민석 ${ }^{1}$ - 김형욱 ${ }^{1,3, *}$ - 김양도 ${ }^{2, *}$ \\ 1재료연구소 금속재료연구본부 알루미늄연구실 \\ ${ }^{2}$ 부산대학교 재료공학부 \\ 3과학기술연합대학원대학교 신소재공학과
}

\title{
Effect of Pre-Aging Treatment on Bake-Hardenability of Al-8.0Zn-2.5Mg-2.0Cu Alloy Sheet Fabricated by Twin-Roll Casting Process
}

\author{
Ji-Goo Heo ${ }^{1,2}$, Yun-Soo Lee ${ }^{1}$, Min-Seok Kim ${ }^{1}$, Hyoung-Wook Kim ${ }^{1,3, *}$, and Yang-Do Kim ${ }^{2, *}$ \\ ${ }^{1}$ Metallic Materials Division, Korea Institute of Materials Science (KIMS), Changwon 51508, Republic of Korea \\ ${ }^{2}$ Department of Materials Science and Engineering, Pusan National University, Busan 46269, Republic of Korea \\ ${ }^{3}$ Department of Advanced Materials Engineering, Korea University of Science and Technology (UST), Daejeon 34113, \\ Republic of Korea
}

\begin{abstract}
The effects of natural and pre-aging on the microstructure and mechanical properties of $\mathrm{Al}$ $8.0 \mathrm{Zn}-2.5 \mathrm{Mg}-2.0 \mathrm{Cu}$ aluminum alloy sheet fabricated by twin roll casting were investigated. Immediately after solution treatment, the $\mathrm{Al}-8.0 \mathrm{Zn}-2.5 \mathrm{Mg}-2.0 \mathrm{Cu}$ alloy sheet had a yield strength of $173 \mathrm{MPa}$ and elongation of $19.5 \%$. The hardness of the $\mathrm{Al}-8.0 \mathrm{Zn}-2.5 \mathrm{Mg}-2.0 \mathrm{Cu}$ alloy sheet increased sharply for 48 hours with natural aging and then increased gradually for up to 336 hours. After 1 week of natural aging, the yield strength was $371 \mathrm{MPa}$ and the elongation was $12.5 \%$. The yield strength after bake hardening treatment at $180{ }^{\circ} \mathrm{C}$ for 30 minutes was $519 \mathrm{MPa}$ immediately after solution treatment, $534 \mathrm{MPa}$ after natural aging. The fine GP zones generated by natural aging caused local deformation in the aluminum matrix, which reduced the elongation. In addition, they were mostly dissolved during the bake hardening treatment, and some GP zones served as the nuclei of the metastable $\eta^{\prime}$. Pre-aging at $120^{\circ} \mathrm{C}$ for 10 minutes minimized the decrease in elongation by natural aging, and improved the yield strength after baking hardening. The elongation before bake hardening treatment increased to $21 \%$, and the yield strength after bake hardening treatment increased to $573 \mathrm{MPa}$.
\end{abstract}

(Received April 1, 2019; Accepted May 9, 2019)

Keywords: Al-Zn-Mg-Cu alloy, twin roll casting, pre-aging, precipitation, mechanical properties

\section{1. 서 론}

자동차의 연비규제 및 이산화탄소 배출량의 규제가 심화 됨에 따라 차체의 경량화는 더 이상 선택이 아닌 필수다. 경량화를 위해 기존 철강 소재를 대체하기 위한 경량 소재 중 하나인 알루미늄 합금은 비강도, 내식성, 재활용성 등이

- 허지구: 석사과정, 이윤수 · 김민석 · 김형욱: 연구원, 김양도: 교수

*Corresponding Author: Hyoung-Wook Kim

[Tel: +82-55-280-3305, E-mail: hwkim@kims.re.kr]

*Corresponding Author: Yang-Do Kim

[Tel: +82-51-510-3047, E-mail: yangdo@pusan.ac.kr]

Copyright (C) The Korean Institute of Metals and Materials
우수하여 점차 그 활용범위가 확대되고 있다 [1-4]. 현재 자동차 차체에 적용되고 있는 알루미늄 합금 판재로 강도 와 성형성이 우수한 가공 경화형 $\mathrm{Al}-\mathrm{Mg}$ 계(5000계) 판재와 소부경화성이 뛰어난 시효 경화형 $\mathrm{Al}-\mathrm{Mg}-\mathrm{Si}$ 계(6000계) 판 재가 주로 사용 되고 있다 [5]. 최근에는 경량화 효율이 높고 보다 고강도인 차체를 제조하기 위하여 비강도가 우 수한 $\mathrm{Al}-\mathrm{Zn}-\mathrm{Mg}-\mathrm{Cu}$ 계(7000계) 합금을 차체에 적용하기 위 한 연구가 진행되고 있다 [6-8].

일반적인 알루미늄 차체 제작 과정은 판재 프레스 성형 한 차체 부품에 대하여 표면처리 및 도장 공정을 거친 후, 페인트 경화를 위해 $170 \sim 180{ }^{\circ} \mathrm{C}$ 에서 $20 \sim 30$ 분 동안 
Table 1. Chemical composition of Al-8.0Zn-2.5Mg-2.0Cu alloy sheets fabricated by twin roll strip casting and rolling processes.

\begin{tabular}{cccccccccc}
\hline wt $\%$ & $\mathrm{Si}$ & $\mathrm{Fe}$ & $\mathrm{Cu}$ & $\mathrm{Mn}$ & $\mathrm{Mg}$ & $\mathrm{Cr}$ & $\mathrm{Zn}$ & $\mathrm{Ti}$ & $\mathrm{Al}$ \\
\hline $\mathrm{ICP}$ & 0.030 & 0.19 & 2.00 & 0.089 & 2.68 & 0.23 & 7.93 & 0.029 & bal. \\
\hline
\end{tabular}

소부경화처리를 하는 과정으로 구성된다 [9,10]. Al-Zn$\mathrm{Mg}-\mathrm{Cu}$ 계 알루미늄 합금은 시효 경화형 합금으로, 소부경 화처리 공정에서 시효 석출을 통한 추가적인 강도 향상을 기대할 수 있다. 그러나 용체화 처리 후 프레스 성형까지 운송 및 보관 과정에서 불가피하게 상온에 방치됨에 따라 자연 시효 과정을 거치게 되며, 판재의 물성은 용체화 처 리 직후와 차이를 나타낸다 [3,11]. 대표적인 $\mathrm{Al}-\mathrm{Zn}-\mathrm{Mg}-$ $\mathrm{Cu}$ 계 합금인 7075 합금의 경우 용체화 처리 후 자연시효 과정에서 연신율의 저하는 작다고 알려져 있으나 [12,13], 항복강도가 급격히 증가하며 이는 성형 압력을 증가시킬 뿐만 아니라 스프링백(Spring-back) 발생 정도를 심화시킨 다 [14]. 또한 용체화 처리 후 자연시효된 7075 합금을 소부경화처리할 경우, 불균일하고 조대한 시효 석출상 $\left(\mathrm{MgZn}_{2}\right)$ 이 형성되어 강도 상승을 저해하는 것으로 보고되 었다 [13]. 또한 기존 차체용으로 사용되는 Al-Mg-Si계 합 금의 경우에는 예비시효(Pre-aging) $[3,15,16]$ 및 예비변형 (Pre-straning) [16-18] 등의 도입에 의한 자연시효 억제를 통하여 소부경화능을 향상시키는 방안에 대한 연구가 다수 진행되어 왔으나, $\mathrm{Al}-\mathrm{Zn}-\mathrm{Mg}-\mathrm{Cu}$ 계 합금에 대한 자연시효 억제 및 이를 통한 소부경화성 향상에 대한 연구는 많지 않다

본 연구에서는 박판주조법으로 제조한 고강도 $\mathrm{Al}-8.0 \mathrm{Zn}-$ $2.5 \mathrm{Mg}-2.0 \mathrm{Cu}$ 합금 판재의 소부경화특성에 미치는 자연시 효 및 예비시효의 영향에 대하여 조사하였다. 용체화처리 후 자연시효 및 소부경화처리 등 열처리공정에 따른 기계 적 특성 변화를 확인하였으며, 예비시효처리 공정의 도입 을 통한 소부경화능의 향상 가능성을 검토하였다. 또한 미 세조직 및 시효거동 분석을 통하여 예비시효처리가 소부경 화처리 후 최종 $\mathrm{Al}-8.0 \mathrm{Zn}-2.5 \mathrm{Mg}-2.0 \mathrm{Cu}$ 합금 판재의 기계 적 특성 변화에 미치는 영향에 대하여 고찰하였다.

\section{2. 실험방법}

본 실험에서 사용한 $\mathrm{Al}-8.0 \mathrm{Zn}-2.5 \mathrm{Mg}-2.0 \mathrm{Cu}$ 합금 판재는 박판주조공정(twin roll casting, TRC)으로 제조하였다. 박 판주조법은 용탕으로부터 주조와 열간압연을 단일공정으로 수행하는 공정생략형 저비용 제조공정이기 때문에 소재의 가격경쟁력 측면에서 유리한 장점이 있다. 또한, 냉각 속도 가 $10^{3} \mathrm{C} / \mathrm{s}$ 정도로 매우 크기 때문에 미세한 주조 조직을
얻을 수 있으며, 정출상의 크기를 미세화할 수 있는 장점 이 있다 $[19,20]$. 전기로를 사용하여 $720^{\circ} \mathrm{C}$ 에서 $\mathrm{Al}, \mathrm{Zn}$ 및 $\mathrm{Al}-\mathrm{Mg}, \mathrm{Al}-\mathrm{Cu}$ 모합금을 용해한 후, 아르곤가스 주입 하에 10 분간 교반하여 탈가스처리를 하였다. 준비된 알루 미늄합금 용탕을 $690{ }^{\circ} \mathrm{C}$ 에서 안정화시킨 후, 노즐로 주입 하여 박판주조재를 제조하였다 [21]. 제조한 박판주조재의 화학조성을 유도결합 플라즈마 분광분석기(inductively coupled plasma-optical emission spectrometer, ICP-OES, ICAP-6500, Thermo Scientific, UK)를 이용하여 측정하였 으며, 이를 표 1 에 나타내었다.

제조된 초기 두께 $5.5 \mathrm{~mm}$ 인 $\mathrm{Al}-8.0 \mathrm{Zn}-2.5 \mathrm{Mg}-2.0 \mathrm{Cu}$ 합금 판재에 대하여 조직 균질화 및 잔류응력 제거를 목적으로 $400{ }^{\circ} \mathrm{C}$ 에서 1시간 열처리 후, 두께 $3.0 \mathrm{~mm}$ 까지 열간압연을 행하였다. 열간압연된 판재는 다시 $400{ }^{\circ} \mathrm{C}$ 에서 1 시간 열처 리 후 냉간압연하여 두께 $0.8 \mathrm{~mm}$ 의 판재를 제조하였다.

제조한 두께 $0.8 \mathrm{~mm}$ 의 $\mathrm{Al}-8.0 \mathrm{Zn}-2.5 \mathrm{Mg}-2.0 \mathrm{Cu}$ 합금 판 재에 대하여 $470{ }^{\circ} \mathrm{C}$ 에서 1 시간 유지 후 수냉하는 용체화 처리를 실시하였고, 예비시효 및 소부경화처리 등 인공시 효는 오일배스(WHB-11, Daihan, Korea)를 이용하였다. 이 때, 자연시효는 상온에서(평균 $20^{\circ} \mathrm{C}$ ) 수행하였고, 예비시 효처리는 $60 \sim 150{ }^{\circ} \mathrm{C}$ 온도범위에서 $10 \sim 240$ 분간 수행하였 으며, 소부경화처리는 $180{ }^{\circ} \mathrm{C}$ 에서 30 분간 유지 후 수냉하 였다.

용체화처리된 $\mathrm{Al}-8.0 \mathrm{Zn}-2.5 \mathrm{Mg}-2.0 \mathrm{Cu}$ 합금 판재의 미세 조직 관찰을 위해 연마기(polishing machine, ALLIED)를 이용하여 기계 연마 후 전해 에칭을 하였고, 광학현미경 (optical microscope, OM, Nikon, MA200)을 이용하여 미세조직을 관찰하였다.

판재의 시효처리 조건에 따른 경도 값 변화는 마이크로 비커스경도계(HM-122, Mitutoyo, Japan)를 이용하여 측정하 였으며, 경도측정은 하중 $200 \mathrm{~g}$, 유지시간 9초의 조건으로 실시하였다. 강도 및 연신율의 특성변화는 인장시험기(Instron 5982, Instron, USA)로 측정하였으며, ASTM E-8M 규격에 따라 압연방향과 인장방향이 일치하도록 시편을 채취하였다. 인장시험 시 cross head speed는 $1.5 \mathrm{~mm} / \mathrm{min}$ 이였으며, 연 신율은 $25 \mathrm{~mm}$ 신장계를 이용하여 측정하였다.

자연시효 및 인공시효처리 조건 변화에 따른 석출물의 생 성 거동을 파악하기 위해 시차주사열량기(differential scanning calorimeter, DSC, Pyris Diamond DSC, Perkin- 
Elmer, USA)를 이용하여 열량변화를 측정하였다. 시편은 약 $30 \sim 40 \mathrm{mg}$ 의 디스크 형으로 채취하였으며, $20.0 \mathrm{ml} / \mathrm{min}$ 의 질소 가스 분위기에서 $10{ }^{\circ} \mathrm{C} / \mathrm{min}$ 의 승온 속도로 열량정 보를 분석하였다. 또한, 생성상 관찰 및 분석을 위해 가속 전압이 $160 \mathrm{kV}$ 인 투과전자현미경(transmission electron microscopy, TEM, JEOL-2100F, JEOL, Japan)을 이용하 였다. 관찰용 시편은 두께 $80 \sim 100 \mu \mathrm{m}$ 크기의 박편을 기 계적인 연마로 제조하고 Nital $\left(25 \% \mathrm{HNO}_{3}+75 \% \mathrm{CH}_{3} \mathrm{OH}\right)$ 용액을 이용하여 $-20{ }^{\circ} \mathrm{C}, 15 \mathrm{~V}$ 조건에서 제트폴리싱 $(\mathrm{jet}$ polishing)하였다.

\section{3. 실험결과}

\section{1 박판주조 $\mathrm{Al}-8.0 \mathrm{Zn}-2.5 \mathrm{Mg}-2.0 \mathrm{Cu}$ 합금 판재의 자연시효 거동}

용체화처리된 $\mathrm{Al}-8.0 \mathrm{Zn}-2.5 \mathrm{Mg}-2.0 \mathrm{Cu}$ 초기 소재의 표면 부터 중심부까지의 단면(transverse direction, TD)을 관찰 한 미세조직을 그림 1 에 나타내었다. 그 결과 판재 표면부 의 경우 약 $6.9 \mu \mathrm{m}$, 중심부의 경우 약 $7.1 \mu \mathrm{m}$ 로 결정립 크기의 편차가 거의 없는 완전히 재결정된 미세한 등축정 의 미세조직으로 이루어진 것을 확인할 수 있었다.

용체화처리된 $\mathrm{Al}-8.0 \mathrm{Zn}-2.5 \mathrm{Mg}-2.0 \mathrm{Cu}$ 합금 판재의 자연 시효에 따른 경도 변화를 측정하여 그림 2에 나타내었다. 그 결과 경도 값은 용체화처리 직후 (자연시효 10분) 95 $\mathrm{Hv}$ 에서 자연시효 시간의 경과에 따라 48시간까지 급격히 상승하여 $147 \mathrm{Hv}$ 로 나타났고, 48시간 이후에는 완만하게 증가하는 것을 확인 할 수 있었다. 이러한 결과는 Al$8.0 \mathrm{Zn}-2.5 \mathrm{Mg}-2.0 \mathrm{Cu}$ 합금 대비 $\mathrm{Zn}$ 및 $\mathrm{Mg}$ 첨가량이 비교

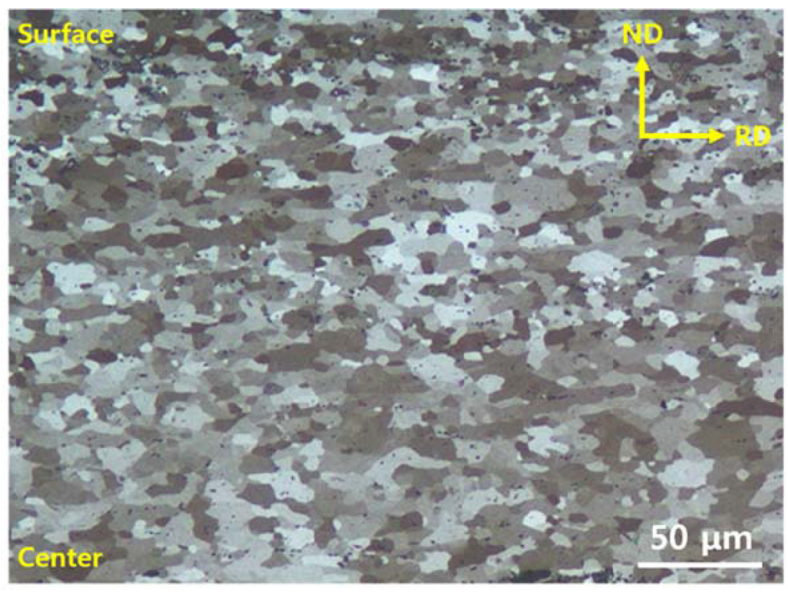

Fig. 1. Microstructure of the solution treated $\mathrm{Al}-8.0 \mathrm{Zn}-2.5 \mathrm{Mg}$ $2.0 \mathrm{Cu}$ alloy sheet $(\mathrm{RD}=$ Rolling Direction, $\mathrm{ND}=$ Normal Direction).
적 낮은 A7075 합금의 자연시효 거동과는 차이가 있었다. 기존 보고된 A7075 합금 박판주조재의 경우 유사한 가공 및 열처리 공정을 거쳤으나 약 96시간 자연시효 시 경도 값이 수렴하는 것으로 확인되었다 [12]. 본 연구에서는 충 분한 자연시효가 진행되었다고 판단되는 용체화처리 후 1 주일(168시간) 동안 상온에서 방치하는 것을 자연시효 조 건으로 설정하였다.

자연시효 유/무에 따른 $\mathrm{Al}-8.0 \mathrm{Zn}-2.5 \mathrm{Mg}-2.0 \mathrm{Cu}$ 합금 판 재의 소부경화처리 전/후 인장특성 변화를 그림 3에 비교 하여 나타내었다. 용체화처리 직후 인장강도 $397 \mathrm{MPa}$, 항복 강도 $173 \mathrm{MPa}$, 연신율 $19.5 \%$ 수준을 나타내었으나, 1 주일 간의 자연시효 후 인장강도 $538 \mathrm{MPa}$, 항복강도 $371 \mathrm{MPa}$,

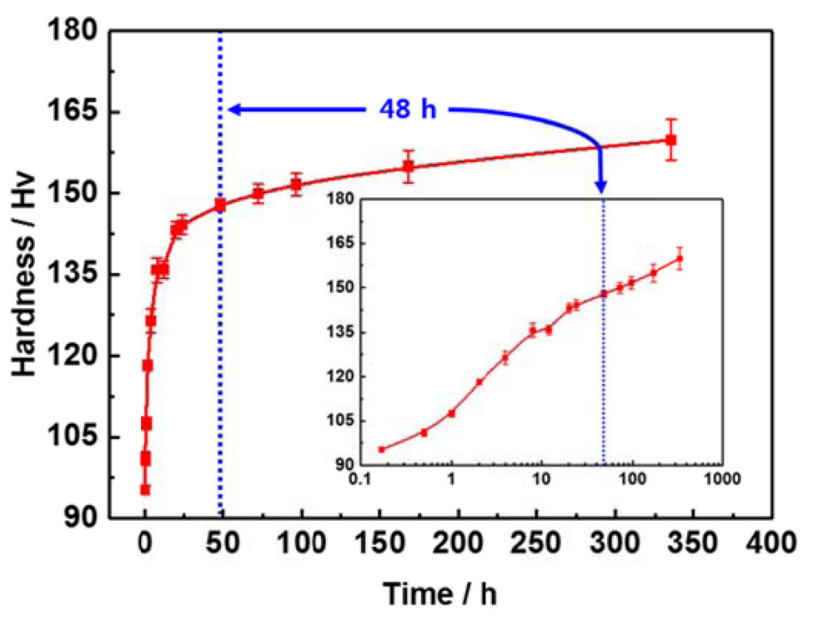

Fig. 2. Effect of natural aging time on micro-Vickers hardness of the solution treated $\mathrm{Al}-8.0 \mathrm{Zn}-2.5 \mathrm{Mg}-2.0 \mathrm{Cu}$ sheet.

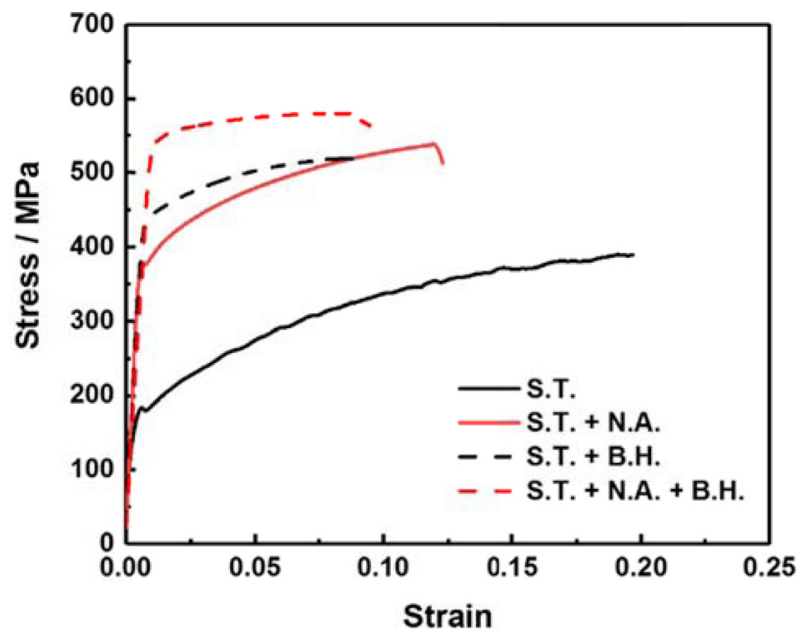

Fig. 3. Effect of natural aging on the mechanical properties before and after bake hardening of Al-8.0Zn-2.5Mg-2.0Cu sheets (S.T.: Solution Treated at $470^{\circ} \mathrm{C}$ for $1 \mathrm{~h}$, N.A.: Natural Aging for 1 week, B.H.: Bake Hardened at $180{ }^{\circ} \mathrm{C}$ for $30 \mathrm{~min}$ ). 

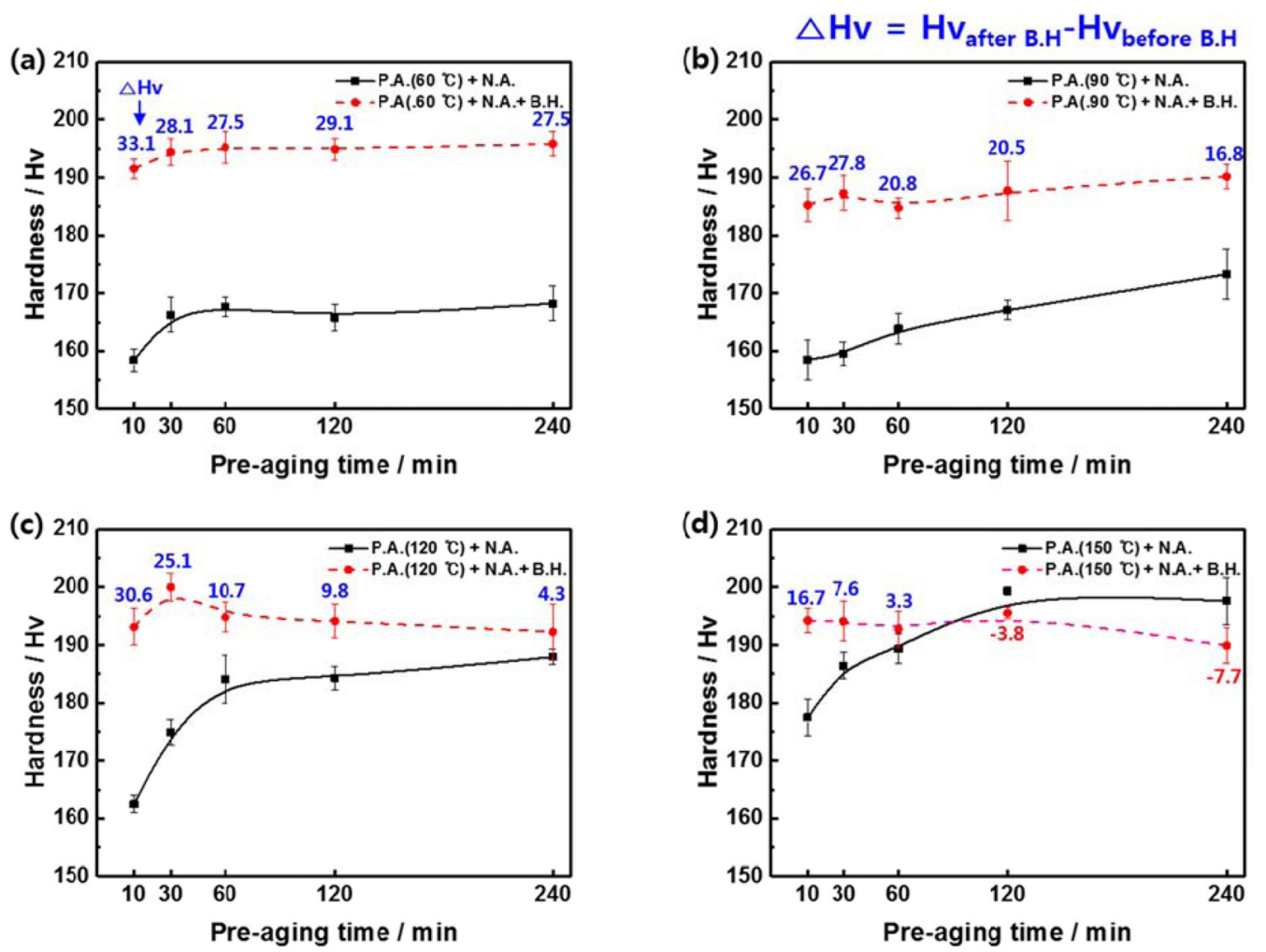

Fig. 4. Micro-Vickers hardness of Al-8.0Zn-2.5Mg-2.0Cu sheets before and after bake hardening at $180{ }^{\circ} \mathrm{C}$ for 30 min: the pre-aged (P.A.) at (a) $60{ }^{\circ} \mathrm{C}$, (b) $90{ }^{\circ} \mathrm{C}$, (c) $120{ }^{\circ} \mathrm{C}$, (d) $150{ }^{\circ} \mathrm{C}$.

연신율 $12.5 \%$ 로 강도가 급증하였지만 연신율의 저하가 매 우 크게 나타났다. 또한, 용체화처리 직후 소부경화처리 한 경우 인장강도 $519 \mathrm{MPa}$, 항복강도 $436 \mathrm{MPa}$, 연신율 $9.0 \%$ 의 수준을 보였으나, 1 주일 간 자연시효 후 소부경화 처리 한 경우 인장강도 $580 \mathrm{MPa}$, 항복강도 $534 \mathrm{MPa}$, 연 신율 $9.3 \%$ 수준으로 강도가 향상되었다. 일반적인 차체 제 작 공정을 고려하면 용체화처리 후 차체 성형을 수행하기 때문에 높은 연신율 및 낮은 항복강도의 확보가 중요하며, 최종 소부경화처리 후에는 내덴트성(dent resistance) 확보 를 위한 높은 항복강도가 요구된다. 그러므로 앞서 확인된 $\mathrm{Al}-8.0 \mathrm{Zn}-2.5 \mathrm{Mg}-2.0 \mathrm{Cu}$ 합금판재의 자연시효에 의한 급격 한 연신율 저하는 차체 성형의 자유도를 제한하며, 따라서 자연시효의 억제를 통한 연신율의 확보가 필요할 것으로 판단된다.

\section{2 박판주조 Al-8.0Zn-2.5Mg-2.0Cu 합금 판재의 예비시효 거동}

자연시효에 의한 연신율의 저하를 억제하기 위한 목적으 로 본 연구에서는 $\mathrm{Al}-8.0 \mathrm{Zn}-2.5 \mathrm{Mg}-2.0 \mathrm{Cu}$ 합금에 대하여 예비시효 공정을 도입하고자 하였다. 용체화처리 후 각각
$60,90,120,150{ }^{\circ} \mathrm{C}$ 에서 10 분부터 240 분까지 예비시효처 리를 수행하고 1 주일간 자연시효를 수행한 판재에 대하여 소부경화처리 전/후 경도측정을 실시하고, 이를 그림 4에 나타내었다. 이 때, 소부경화처리 전/후의 경도 값 증가분 을 $\Delta \mathrm{Hv}\left(\mathrm{Hv}_{\mathrm{afterB.H}}-\mathrm{Hv}_{\mathrm{beforeB.H} .}\right)$ 로 나타내었다. 그림 $4(\mathrm{a})$ 는 $60{ }^{\circ} \mathrm{C}$ 에서 예비시효처리한 경우이며, 10 분간 예비시효처리 한 경우 $158 \mathrm{Hv}, 240$ 분 동안 예비시효처리한 경우 168 $\mathrm{Hv}$ 로 경도 값의 차이가 크지 않았다. 소부경화처리 후에는 각각 $186 \mathrm{Hv}$ 와 $195 \mathrm{Hv}$ 로 경도 값이 약 $30 \mathrm{Hv}$ 증가하 였으며, $60{ }^{\circ} \mathrm{C}$ 에서 10 분간 예비시효처리한 경우 경도 값의 증가분 $(\Delta \mathrm{Hv})$ 이 $33.1 \mathrm{Hv}$ 로 가장 높았다. 그림 $4(\mathrm{~b})$ 는 $90{ }^{\circ} \mathrm{C}$ 에서 예비시효처리한 경우이며, 10 분간 예비시효처리 한 경우 $158 \mathrm{Hv}, 240$ 분 동안 예비시효처리한 경우 173 $\mathrm{Hv}$ 로 경도 값의 차이가 크지 않았고, $60{ }^{\circ} \mathrm{C}$ 에서 예비시효 처리한 경우와 비슷한 경향을 보였다. 소부경화처리 후에 는 각각 $181 \mathrm{Hv}$ 와 $190 \mathrm{Hv}$ 로 $90{ }^{\circ} \mathrm{C}$ 에서 30 분간 예비시효 처리한 경우 $\Delta \mathrm{Hv}$ 가 $27.8 \mathrm{Hv}$ 로 가장 높았다. 그림 4(c)는 $120^{\circ} \mathrm{C}$ 에서 예비시효처리한 경우이며, 10 분간 예비시효처 리한 경우 $162 \mathrm{Hv}$ 였고, 60 분까지 경도 값이 급격히 증가 하였다. 소부경화처리 후에는 예비시효처리 시간이 증가할 
수록 경도 값이 감소하며, $120^{\circ} \mathrm{C}$ 에서 10 분간 예비시효처 리한 경우 $\Delta \mathrm{Hv}$ 가 $30.6 \mathrm{Hv}$ 로 가장 높았다. 그림 $4(\mathrm{~d})$ 는 $150{ }^{\circ} \mathrm{C}$ 에서 예비시효처리한 경우이며, 10 분간 예비시효처 리한 경우 $177 \mathrm{Hv}, 240$ 분 동안 예비시효처리한 경우 198 $\mathrm{Hv}$ 로 시효처리 경과에 따른 경도 값의 상승폭이 다른 예 비시효처리 온도와 비교하여 매우 두드러졌다. 그러나, 추 가적으로 $180{ }^{\circ} \mathrm{C}$ 에서 30 분간 소부경화처리를 실시한 경우 예비시효시간이 증가함에 따라 소부경화처리 후의 경도 값 이 소부경화처리 전보다 오히려 감소하였다. 이는 예비시 효 온도가 높아 유지시간이 증가함에 따라 소부경화처리 전 $\eta^{\prime}$ 상이 대부분 석출되어, 추가적인 소부경화처리 시 석출상 이 조대화 되거나 $\eta$ 상으로 변태함으로써 과시효가 발생하여 경도 값이 감소하는 것으로 판단된다 [22,23]. 차체용 판재 로 사용하기위해서는 소부경화처리 전 높은 성형성을 나타 내야하고 소부경화처리 후에는 높은 항복강도를 나타내는 것이 요구된다. 즉 소부경화처리 전 경도 값이 낮고, 소부경 화처리 후 경도 값 증가분이 큰 조건이 바람직하다. 따라서 $60,90,120^{\circ} \mathrm{C}$ 에서 10 분간 예비시효처리를 수행하는 조건을 각 온도별 최적 조건으로 선정하였고, 소부경화처리 전 경 도 값 향상이 크고 소부경화처리 후 경도 값 증가분이 작은 $150{ }^{\circ} \mathrm{C}$ 는 부적절한 예비시효처리 온도라고 판단하였다.

앞서 선정된 예비시효처리 조건 $\left(60,90,120^{\circ} \mathrm{C} \mathrm{X} 10\right.$ 분)을 달리한 인장시편을 준비하고 소부경화처리 전/후 인 장시험을 실시하여 그 결과를 그림 5 에 나타내었다. $60{ }^{\circ} \mathrm{C}$ 에서 10 분간 예비시효처리 후 일주일간 자연시효한 경우 인장강도 $542 \mathrm{MPa}$, 항복강도 $386 \mathrm{MPa}$, 연신율 $10.7 \%$ 이 고, 소부경화처리 후 인장강도 $586 \mathrm{MPa}$, 항복강도 $548 \mathrm{MPa}$, 연신율 $10.2 \%$ 로 소부경화처리 후의 항복강도는 증가하였으나 소부경화처리 전 낮은 연신율을 나타내었다. $90{ }^{\circ} \mathrm{C}$ 에서 10 분간 예비시효처리 후 자연시효한 경우에는 인장강도 $581 \mathrm{MPa}$, 항복강도 $399 \mathrm{MPa}$, 연신율 $17.9 \%$ 이 고, 소부경화처리 후 인장강도 $603 \mathrm{MPa}$, 항복강도 $556 \mathrm{MPa}$, 연신율 $11.1 \%$ 로 소부경화처리 전 비교적 큰 파 단연신율과 소부경화처리 후 추가적인 강도 향상도 관찰되 었다. 마지막으로 $120{ }^{\circ} \mathrm{C}$ 에서 10 분간 예비시효처리 후 자 연시효한 경우 인장강도 $566 \mathrm{MPa}$, 항복강도 $410 \mathrm{MPa}$, 연 신율 $21 \%$ 이고, 소부경화처리 후 인장강도 $608 \mathrm{MPa}$, 항 복강도 $573 \mathrm{MPa}$, 연신율 $9 \%$ 로 소부경화처리 전 가장 높 은 파단연신율과 소부경화처리 후 가장 우수한 항복강도를 나타내었다. 결론적으로 경도 및 인장특성 평가를 통하여 $\mathrm{Al}-8.0 \mathrm{Zn}-2.5 \mathrm{Mg}-2.0 \mathrm{Cu}$ 합금에 대한 예비시효처리의 도입 은 자연시효에 의한 연신율 저하를 억제하고, 부가적인 강 도 향상 또한 확보할 수 있음을 확인하였다.

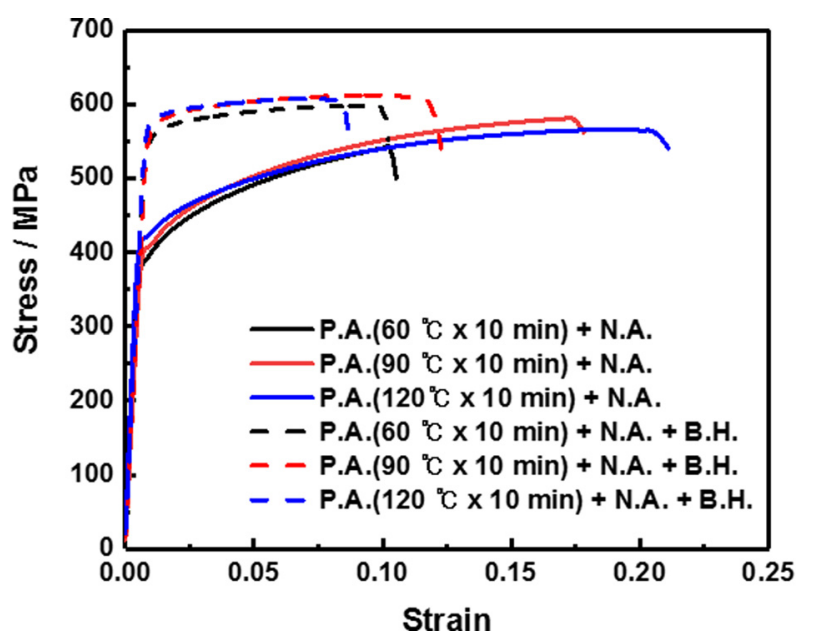

Fig. 5. Tensile properties before and after bake-hardening treatment according to pre-aging conditions

\section{4. 고 찰}

앞서 언급한 바와 같이, 자연시효 시간의 증가에 따라 경도 값이 수렴하는 A7075 (Al-5.5Zn-2.5Mg-1.5Cu) 합금 과 달리 본 연구에서 사용한 $\mathrm{Al}-8.0 \mathrm{Zn}-2.5 \mathrm{Mg}-2.0 \mathrm{Cu}$ 합금 의 경우 336시간(2주)까지 지속적인 경도 값 증가를 나타 내었다. 열역학계산 소프트웨어인 FactSage (버전 7.2)를 사용하였으며, FTlite (FactSage light metal intermetallic compounds and alloy solutions) 데이터베이스를 활용하여 $\mathrm{A} 7075$ 및 $\mathrm{Al}-8.0 \mathrm{Zn}-2.5 \mathrm{Mg}-2.0 \mathrm{Cu}$ 알루미늄 합금의 온도에 따른 주요 첨가원소 $(\mathrm{Zn}, \mathrm{Mg}, \mathrm{Cu})$ 의 알루미늄 기지내 고용 도를 계산하고, 이를 그림 6에 나타내었다. 그 결과 Al$8.0 \mathrm{Zn}-2.5 \mathrm{Mg}-2.0 \mathrm{Cu}$ 합금의 경우 $\mathrm{A} 7075$ 합금 대비 $\mathrm{Zn}$ 및 $\mathrm{Cu}$ 의 첨가량이 높기 때문에, 용체화처리 온도인 $470{ }^{\circ} \mathrm{C}$ 에서 기지 내에 높은 $\mathrm{Zn}$ 및 $\mathrm{Cu}$ 고용도를 나타내는 것으로 확인되었다. 특히 다량 고용된 $\mathrm{Zn}$ 는 $\mathrm{Mg}$ 과 함께 $\mathrm{Al}-\mathrm{Zn}-\mathrm{Mg}-\mathrm{Cu}$ 계 합금의 주 시효석출상인 $\eta\left(\mathrm{MgZn}_{2}\right)$ 상을 형 성시킨다. $\eta\left(\mathrm{MgZn}_{2}\right)$ 상의 경우 $\mathrm{Zn}$ 와 $\mathrm{Mg}$ 의 결합 질량비는 $5.38: 1$ 수준이므로, 기지 내 $\mathrm{Zn}$ 의 고용량 증가는 자연시효 에 대한 구동력을 충분히 높여 GP zone의 형성을 촉진함 으로써 경도 값을 지속적으로 증가시키는 것으로 판단된다 (표 2) [24]. 또한 $\mathrm{Cu}$ 의 경우에도 기지 내에 고용되어 자 연시효의 속도를 증가시키는 것으로 알려져 있으므로 [25], 자연시효에 의한 소재의 경화가 더욱 증대되는 것으로 판 단된다.

자연시효에 의한 기계적 특성 변화의 원인을 조사하기 위해 DSC 분석을 실시하였고, 그 결과를 그림 7에 나타 내었다. 지금까지 알려진 일반적인 7000계 합금의 시효거 

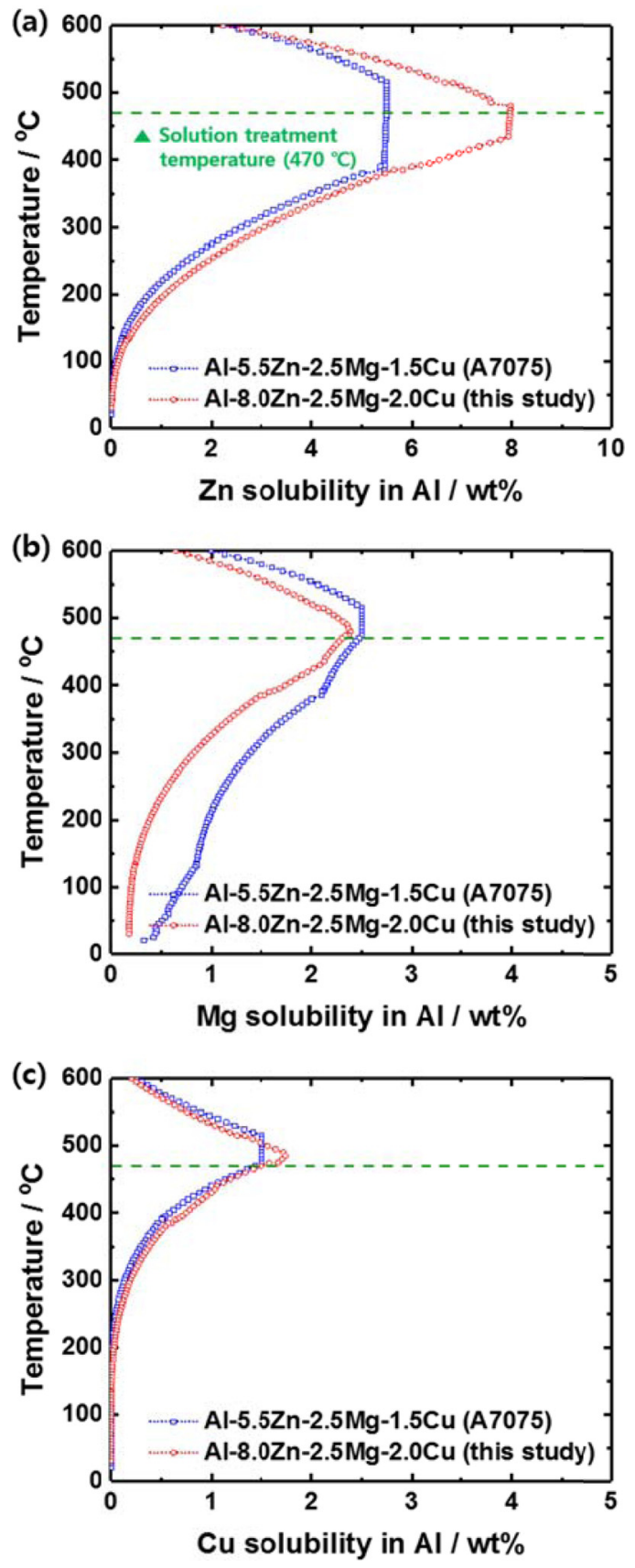

Fig. 6. Thermodynamically calculated (a) $\mathrm{Zn}$, (b) $\mathrm{Mg}$, (c) $\mathrm{Cu}$ solubility in aluminum matrix in $\mathrm{Al}-\mathrm{Zn}-\mathrm{Mg}-\mathrm{Cu}$ alloys.
동은 다음과 같다 [26-29].

SSSS (Supersaturated solid solution) $\rightarrow$ GP zones

$\rightarrow \eta^{\prime} \rightarrow \eta$

$\mathrm{Al}-\mathrm{Zn}-\mathrm{Mg}-\mathrm{Cu}$ 계 합금의 시효거동에 대한 기존 연구 결과 에서는 용체화처리에 의해 생성된 과포화 고용체(SSSS)에 서 $\mathrm{Zn}, \mathrm{Mg}$ 이 풍부한 구형의 GP zone이 점진적으로 생성 되고 시효처리 과정에서 주요강화상인 $\eta^{\prime}$ 상으로 변태되거 나 용해되는 것으로 알려져 있다 [30,31]. 용체화처리된 $\mathrm{Al}-8.0 \mathrm{Zn}-2.5 \mathrm{Mg}-2.0 \mathrm{Cu}$ 합금 판재의 경우, $90{ }^{\circ} \mathrm{C} \sim 300^{\circ} \mathrm{C}$ 범위에서 4 개의 피크가 관찰된다. 피크 1,2 는 각각 $\mathrm{GP}$ zone 용해와 $\eta^{\prime}$ 상 석출과 관련이 있고, 피크 3 은 $\eta^{\prime} \rightarrow$ $\eta\left(\eta_{2}\right)$ 변태, 피크 4는 $\eta\left(\eta_{1}\right)$ 석출과 관련이 있다 [30,32]. 용체화처리 후 1 주일간 자연시효한 경우, GP zone 용해 및 $\eta^{\prime}$ 상의 석출피크가 증가되었으며, 이는 자연시효에 의 해 생성된 다량의 GP zone이 승온 시 $\eta^{\prime}$ 상 석출을 용이 하게 하는 것으로 판단된다 [29]. 즉, 그림 2 및 그림 3에 서 확인한 자연시효에 의한 경도, 강도 증가 및 연신율 감 소는 용체화처리 후 자연시효에 의해 생성된 다수의 GP zone에 의한 것으로 판단된다 [33,34]. 용체화처리 후 2 주일간 자연시효 한 경우 1 주일간 자연시효한 경우와 유 사한 경향을 보이며, 자연시효 시간이 증가해도 GP zone 용해피크(1)의 크기가 크게 증가하거나 고온부로 이동하지 않는 것으로 보아 일정 크기 이상으로 성장하지 않는 것으 로 판단된다 [30,35].

예비시효처리공정 도입에 의한 기계적 특성 향상의 원인 을 규명하기 위하여 미세조직(TEM) 및 시효석출상의 용해 /석출 거동(DSC)을 분석하였다. 그림 8에 용체화처리 후 각각 $60,90,120^{\circ} \mathrm{C}$ 에서 10 분간 예비시효처리한 $\mathrm{Al}-$ $8.0 \mathrm{Zn}-2.5 \mathrm{Mg}-2.0 \mathrm{Cu}$ 합금 판재의 $\mathrm{DSC}$ 분석결과를 나타내 었다. $60{ }^{\circ} \mathrm{C}$ 에서 10 분간 예비시효처리 후 자연시효한 경우, 기존 용체화처리 후 자연시효한 DSC 그래프와 유사한 경 향을 보이며 시효온도 및 시간이 충분치 않아 GP zone이 임계크기 이상으로 성장하지 못하여 용해에 의한 흡열반응 이 자연시효한 $\mathrm{Al}-8.0 \mathrm{Zn}-2.5 \mathrm{Mg}-2.0 \mathrm{Cu}$ 판재와 유사하게 나

Table 2. Solubility of $\mathrm{Zn}, \mathrm{Mg}, \mathrm{Cu}$ in aluminum matrix of $\mathrm{Al}-\mathrm{Zn}-\mathrm{Mg}-\mathrm{Cu}$ alloys at solution treatment $\left(470{ }^{\circ} \mathrm{C}, \mathrm{ST}\right)$ and room $\left(25^{\circ} \mathrm{C}, \mathrm{NA}\right)$ temperatures.

\begin{tabular}{|c|c|c|c|c|c|c|}
\hline \multirow{2}{*}{ Alloy } & \multirow{2}{*}{ Temper } & \multirow{2}{*}{ Temperature } & \multicolumn{3}{|c|}{ Solubility in aluminum matrix (wt $\%$ ) } & \multirow{2}{*}{$\mathrm{Zn} / \mathrm{Mg}$ ratio } \\
\hline & & & $\mathrm{Zn}$ & $\mathrm{Mg}$ & $\mathrm{Cu}$ & \\
\hline \multirow{2}{*}{ A7075 } & ST & $470^{\circ} \mathrm{C}$ & 5.497 & 2.308 & 1.431 & 2.38 \\
\hline & NA & $25^{\circ} \mathrm{C}$ & 0.010 & 0.330 & $6.699 \times 10^{-6}$ & - \\
\hline \multirow{2}{*}{ This study } & ST & $470^{\circ} \mathrm{C}$ & 7.966 & 2.308 & 1.497 & 3.45 \\
\hline & NA & $25^{\circ} \mathrm{C}$ & 0.013 & 0.181 & $1.157 \times 10^{-5}$ & - \\
\hline
\end{tabular}




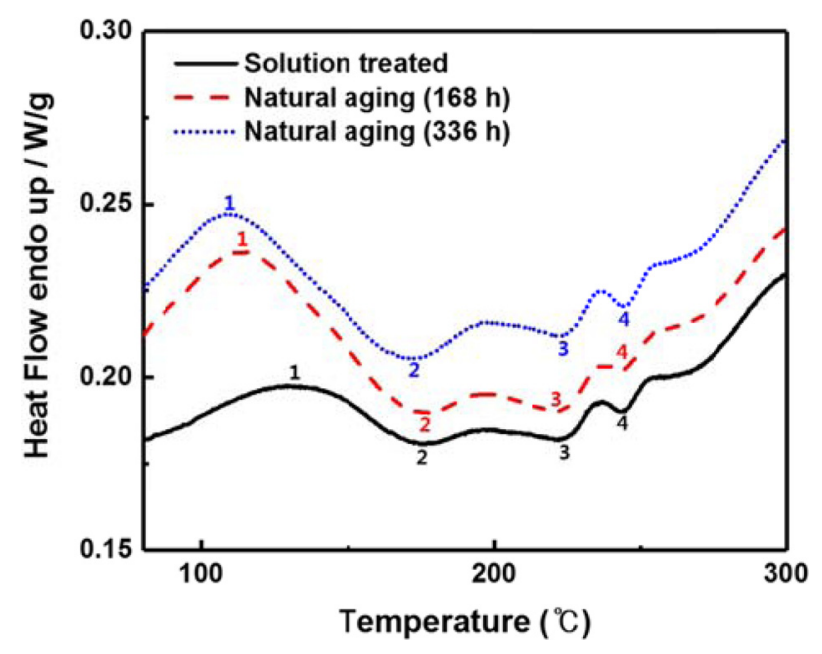

Fig. 7. DSC curves of the $\mathrm{Al}-8.0 \mathrm{Zn}-2.5 \mathrm{Mg}-2.0 \mathrm{Cu}$ sheets after solution treatment and natural aging.

타나는 것을 확인할 수 있다. 임계크기로 성장하지 못한 GP zone은 전위의 이동을 효율적으로 방해하지 못하며, 따 라서 인장변형 시 국부적인 변형을 야기함으로써 낮은 연 신율 특성 (그림 5 , P.A. $\left(60^{\circ} \mathrm{C} \times 10 \mathrm{~min}\right)+$ N.A.)을 나타내 는 것으로 판단된다 $[33,34]$. 반면 $90^{\circ} \mathrm{C}$ 에서 10 분간 예 비시효처리 후 자연시효한 경우 $114^{\circ} \mathrm{C}$ 부근에서 발생하는 $\mathrm{GP}$ zone 용해 피크가 약화되며, 고온부로 약 $10{ }^{\circ} \mathrm{C}$ 정도 이동하였으며, 이는 예비시효과정에서 GP zone의 크기가 성장하였기 때문으로 판단된다. 크기가 성장한 GP zone의 경우 인장변형 중 전위의 이동을 효과적으로 억제할 수 있 기 때문에 소재 내부에 균일한 변형을 야기할 수 있으며, 이로 인하여 인장변형 시 연신율이 크게 향상한 것으로 판 단된다 (그림 5, P.A. $\left(90^{\circ} \mathrm{C} \times 10 \mathrm{~min}\right)+$ N.A.). 마지막으로 $120{ }^{\circ} \mathrm{C}$ 에서 10 분간 예비시효처리 후 자연시효 한 경우 $\mathrm{GP}$ zone 용해피크가 더욱 약화되고 고온부로 이동하게 되는데, $\mathrm{GP}$ zone이 충분히 성장하여 용해온도에서 열적 안정성을 나타내기 때문으로 판단된다.

그림 9는 자연시효 및 예비시효조건에 따른 고배율 미세 조직 사진 및 FFT (Fast Fourier Transformation) 패턴이 며, 주요 상은 GP zone 인 것으로 확인되었다. 그림 9(a) 는 용체화처리 후 자연시효한 경우이며, 알루미늄 기지 내 에 미세한 GP zone이 불균일하게 분포하고 있는 것으로 보인다. 그림 $9(\mathrm{~b})$ 는 $60^{\circ} \mathrm{C}$ 에서 10 분간 예비시효처리 후 자연시효한 경우이며, 예비시효처리를 도입하였음에도 불 구하고 그림 9(a)의 경우와 유사하게 GP zone이 불균일하 게 분포하고 있었다. 그림 $9(\mathrm{c})$ 는 $90{ }^{\circ} \mathrm{C}$ 에서 10 분간 예비 시효처리 후 자연시효한 경우이며, 그림 9(a)의 경우와 비

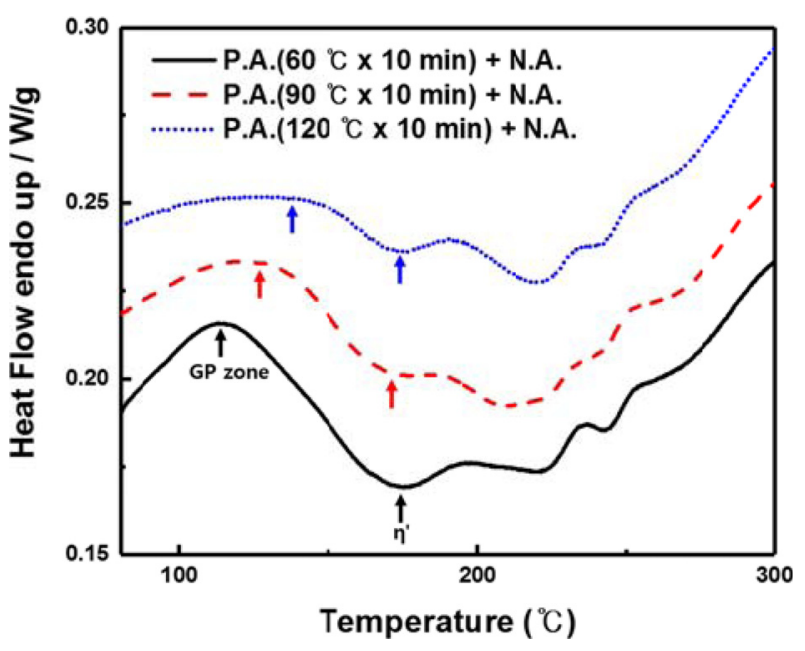

Fig. 8. DSC curves of the $\mathrm{Al}-8.0 \mathrm{Zn}-2.5 \mathrm{Mg}-2.0 \mathrm{Cu}$ sheets pre-aged at $60,90,120{ }^{\circ} \mathrm{C}$ for $10 \mathrm{~min}$ with natural aging for 1 week.
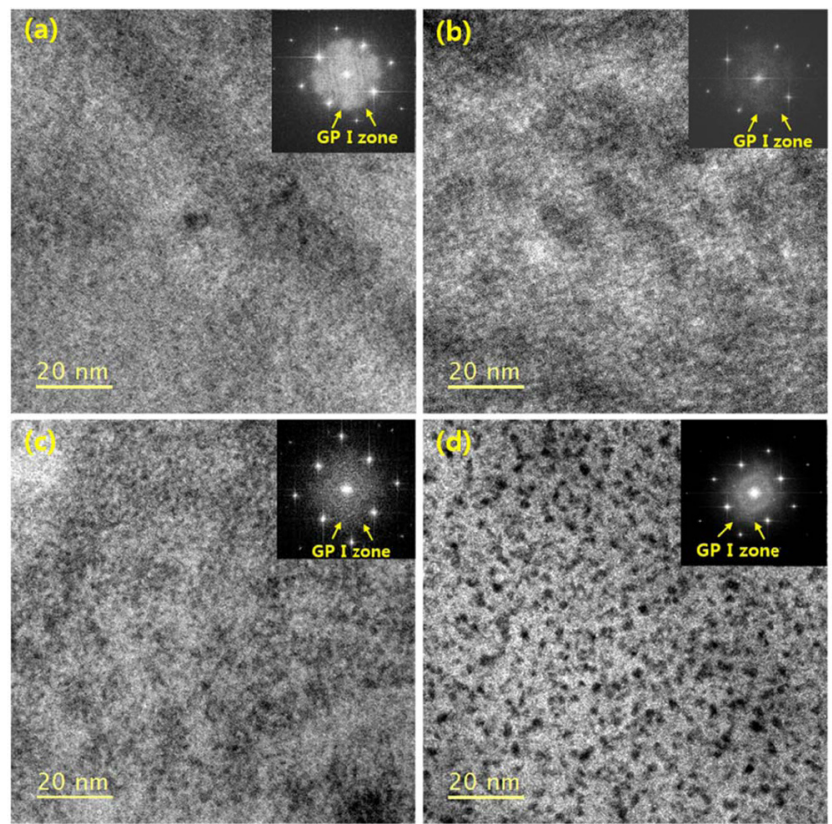

Fig. 9. The TEM micrograph take from natural aged Al-8.0Zn$2.5 \mathrm{Mg}-2.0 \mathrm{Cu}$ sheets in $[001]_{\mathrm{Al}}$ zone axis: (a) without pre-aging, (b) $60{ }^{\circ} \mathrm{C}$ for $10 \mathrm{~min}$, (c) $90^{\circ} \mathrm{C}$ for $10 \mathrm{~min}$, (d) $120^{\circ} \mathrm{C}$ for $10 \mathrm{~min}$.

슷한 분포를 나타내지만 GP zone의 크기가 다소 성장하였 다. 마지막으로 그림 $9(\mathrm{~d})$ 는 $120^{\circ} \mathrm{C}$ 에서 10 분간 예비시효 처리 후 자연시효한 경우이며, 보다 성장된 GP zone이 균 일하게 분포하고 있음을 확인할 수 있었다. 자연시효 또는 낮은 예비시효 온도 $\left(60^{\circ} \mathrm{C}, 10\right.$ 분 $)$ 조건의 경우 $\mathrm{GP}$ zone의 형성이 불균일하여 인장변형 시 국부적인 변형을 유도하여 조기파단을 야기함으로써 낮은 연신율을 나타내는 것으로 판단된다. 반면, 예비시효처리 온도가 높을수록 구형의 GP 
zone이 보다 균일하게 생성되는 것이 관찰되며, 균일하게 분 포하고 있는 GP zone에 의하여 인장변형 시 국부적인 변형 이 억제됨으로써 연신율이 보존되는 것으로 판단된다 [35].

예비시효처리에 의한 소부경화처리 후 강도 향상의 원인 을 분석하기 위해 추가적인 TEM 분석을 실시하였다. 그 림 10 은 자연시효 후 소부경화처리 한 샘플과 기계적특성 이 가장 우수하게 나타난 예비시효조건 $\left(120^{\circ} \mathrm{C} \times 10\right.$ 분 $)$ 에 서 소부경화처리 한 샘플의 고배율 미세조직 사진 및 FFT 패턴을 비교하여 나타낸 것이다. 그림 $10(\mathrm{a})$ 는 자연시효 후 소부경화처리 한 경우이며, 고배율 미세조직 사진에서 얻 어진 FFT 패턴을 분석결과 디스크 형태의 석출물은 $\eta^{\prime}$ 상 의 회절패턴으로 확인되었으나 [36], 그 분포가 균일하지 않고 부피분율이 작았다. 반면 $120^{\circ} \mathrm{C}$ 에서 10 분간 예비시 효처리 후 소부경화처리한 경우(그림 10(b)), $\eta^{\prime}$ 상의 크기 는 비슷하나 분율이 크게 증가하였고 석출물의 분포가 상 대적으로 균일하였다. 앞서 언급한 DSC 분석결과(그림 7, 8) 및 소부경화처리 전 미세조직(그림 9) 결과를 고려하면, 자연시효 또는 낮은 예비시효 온도 $\left(60{ }^{\circ} \mathrm{C}, 10\right.$ 분 $)$ 조건에서 형성된 GP zone의 경우 그 크기가 작아 본 연구에서 사 용한 일반적인 $\mathrm{Al}-\mathrm{Zn}-\mathrm{Mg}-\mathrm{Cu}$ 계 합금의 인공시효처리 온도인 $120^{\circ} \mathrm{C}$ 보다 높은 소부경화처리 온도 $\left(180^{\circ} \mathrm{C}\right)$ 에 의하여 충분 히 용해될 수 있으며 [37], 따라서 핵생성 사이트(nucleation site)가 불충분하여 $\eta^{\prime}$ 상의 생성이 어렵기 때문에 그 분율 이 작고 불균일하여 강도 또한 낮은 것으로 판단된다. 반 면 비교적 높은 온도에서 예비시효처리를 수행한 경우 $\left(120{ }^{\circ} \mathrm{C}, 10\right.$ 분 $)$ 에는 $\mathrm{GP}$ zone의 크기가 충분히 성장하여 $\mathrm{DSC}$ 결과(그림 8)에서도 확인할 수 있는 바와 같이 용해 가 상당히 지연되며, 용해되지 않고 잔류한 $\mathrm{GP}$ zone이 $\eta^{\prime}$ 상의 핵생성 사이트로써 충분한 역할을 할 수 있기 때 문에 높은 분율의 균일한 $\eta^{\prime}$ 상이 형성됨으로써 강도가 향 상된 것으로 판단된다. 결론적으로 본 연구에서 도출한

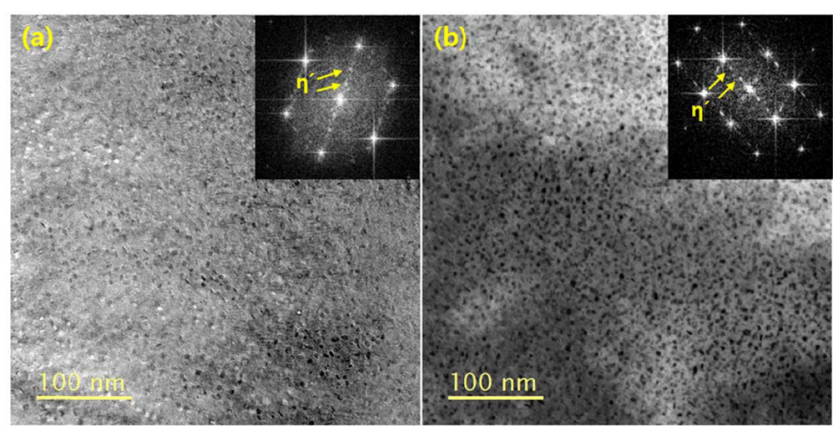

Fig. 10. The TEM micrograph in $[011]_{\mathrm{Al}}$ zone axis of bake hardening treated $\mathrm{Al}-8.0 \mathrm{Zn}-2.5 \mathrm{Mg}-2.0 \mathrm{Cu}$ sheets: (a) without preaging, (b) pre-aged at $120{ }^{\circ} \mathrm{C}$ for $10 \mathrm{~min}$ $120^{\circ} \mathrm{C}$ 에서 10 분 수행하는 예비시효조건의 도입을 통하여 박판주조법으로 제조한 $\mathrm{Al}-8.0 \mathrm{Zn}-2.5 \mathrm{Mg}-2.0 \mathrm{Cu}$ 합금판재의 자연시효에 의한 연신율 감소를 개선하고, 소부경화처리 후 높은 강도 특성을 확보할 수 있음을 확인하였다.

\section{5. 결 론}

본 연구에서는 박판주조법으로 제조한 고강도 $\mathrm{Al}-8.0 \mathrm{Zn}-$ $2.5 \mathrm{Mg}-2.0 \mathrm{Cu}$ 합금판재의 소부경화 특성에 미치는 자연시 효 및 예비시효의 영향에 대하여 미세조직, 기계적 특성 및 열분석 결과의 상관관계를 통하여 고찰하였으며, 다음 과 같은 결론을 얻을 수 있었다.

박판주조 및 압연으로 제조한 두께 $0.8 \mathrm{~mm}$ 인 $\mathrm{Al}-8.0 \mathrm{Zn}-$ $2.5 \mathrm{Mg}-2.0 \mathrm{Cu}$ 합금판재를 용체화처리 후 자연시효 하였을 경우 초기에 경도 값이 급격히 상승하였으나, 72 시간 이후 부터 336시간까지 경도 값이 서서히 증가하였으며, DSC 분석결과 다량의 GP zone의 생성이 경도 상승의 원인으로 판단되었다. 용체화 처리한 직후 판재의 인장특성은 항복 강도 $173 \mathrm{MPa}$, 연신율 $19.5 \%$ 의 수준을 보였으며, 1 주일 동안의 자연시효처리 후에는 항복강도 $371 \mathrm{MPa}$, 연신율 $12.5 \%$ 로 급격한 연신율의 저하를 관찰할 수 있었고, 이는 높은 용질 함량으로 인해 GP zone 생성이 촉진되어 연신 율의 저하가 큰 것으로 판단된다.

$\mathrm{Al}-8.0 \mathrm{Zn}-2.5 \mathrm{Mg}-2.0 \mathrm{Cu}$ 합금판재에 대하여 다양한 예비시 효처리 공정 도입 후 기계적 특성 변화를 분석한 결과, $120{ }^{\circ} \mathrm{C}$ 에서 10 분간 예비시효처리를 도입한 경우 연신율이 $21 \%$ 수준으로, 용체화처리 직후(연신율 $20 \%$ )와 유사한 결 과를 나타내었다. 이는 예비시효에 의하여 임계크기 이상 으로 성장한 GP zone이 알루미늄 기지내 균일한 변형장을 형성하고 따라서 인장 시 균일한 변형을 유도하기 때문에 연신율이 향상된 것으로 판단된다.

$\mathrm{Al}-8.0 \mathrm{Zn}-2.5 \mathrm{Mg}-2.0 \mathrm{Cu}$ 합금판재에 대하여 $120{ }^{\circ} \mathrm{C}$ 에서 10 분간 예비시효처리 후 소부경화처리를 수행할 경우 가장 높은 강도를 나타냈다. 이는 적절한 예비시효처리의 도입 을 통하여 충분히 성장한 GP zone이 소부경화처리 시 보 다 균일한 핵생성 사이트로서 작용함으로써 높은 분율의 균일한 $\eta^{\prime}$ 상이 형성되었기 때문으로 판단된다.

\section{감사의 글}

본 연구는 한국기계연구원 부설 재료연구소 주요사업 (PNK5990)의 연구비 지원으로 수행되었으며, 이에 감사드 립니다. 


\section{REFERENCES}

1. M. Alipour and R. Eslami-Farsani, Mater. Sci. Eng. A 706, 71 (2017).

2. A. Deb, M. Mahendrakumar, C. Chavan, J. Karve, D. Blankenburg, and S. Storen, Int. J. Impact Eng. 30, 1055 (2004).

3. Y. Birol, Mater. Sci. Eng. A 391, 175 (2005).

4. S. Pogatscher, H. Antrekowitsch, H. Leitner, T. Ebner, and P. J. Uggowitzer, Acta Mater. 59, 3352 (2011).

5. J. Hirsch, Mater. Forum 28, 15 (2004).

6. W. Yang, S. Ji, Q. Zhang, and M. Wang, Mater. Des. 85, 752 (2015).

7. M. Kumar, N. Sotirov, and C. Chimani, J. Mater. Process. Techonol. 214, 1769 (2014).

8. Y.-S. Lee, W.-K. Kim, D.-A Jo, C.-Y. Lim, and H.-W. Kim, Trans. Nonferrous Met. Soc. China 24, 2226 (2014).

9. W. C. Jeong and S. H. Han, Korean J. Met. Mater. 54, 483 (2016).

10. P. Ratchev, B. Verlinden, P. De Smet, and P. Van Houtte, Acta Mater. 46, 3523 (1998).

11. J. Gubicza, I. Schiller, N. Q. Chinh, J. Illy, Z. Horita, and T. Langdon, Mater. Sci. Eng. A 460, 77 (2007).

12. D. H. Koh, Y. S. Lee, M. S. Kim, H. W. Kim, and Y. S. Ahn, Korean J. Met. Mater. 54, 483 (2016).

13. Y.-S. Lee, D.-H. Koh, H.-W. Kim, and Y.-S. Ahn, Scr. Mater. 147, 45 (2018).

14. H. Wang, J. Zhou, T. S. Zhao, L. Z. Liu, and Q. Liang, Mater. Des. 102, 247 (2016).

15. T. Abid, A. Boubertakh, and S. Hamamda, J. Alloy. Compd. 490, 166 (2010).

16. T. Masuda, Y. Takaki, T. Sakurai, and S. Hirosawa, Mater. Trans. 51, 325 (2010).

17. Y. Birol, Scr. Mater. 52, 169 (2005).

18. L. Ding, Z. Jia, Y. Liu, Y. Weng, and Q. Liu, J. Alloy. Compd. 688, 362 (2016).
19. L. Wang, H. Yu, Y. Lee, and H.-W. Kim, Met. Mater. Int. 21, $832(2015)$

20. Y.-S. Lee, H.-W. Kim, J.-H. Cho, and S.-H. Chun, Met. Mater. Int. 23, 923 (2017).

21. Y.-S. Lee, H.-W. Kim, and J.-H. Cho, J. Mater. Process. Technol. 218, 48 (2015).

22. K. Wen, Y. Fan, G. Wang, L. Jin, X. Li, Z. Li, Y. Zhang, and B. Xiong, Mater. Des. 101, 16 (2016).

23. D. Liu, B. Xiong, F. Bian, Z. Li, X. Li, Y. Zhang, F. Wang, and H. Liu, Mater. Sci. Eng. A 588, 1 (2013).

24. C. Garcia-Cordovilla and E. Louis, Mater. Sci. Eng. A 132, 135 (1991).

25. A. Deschamps, Y. Bréchet, and F. Livet, Mater. Sci. Technol. 15, 993 (1999).

26. G. Waterloo, V. Hansen, J. Gjønnes, and S. Skjervold, Mater. Sci. Eng. A 303, 226 (2001).

27. M. Starink and S. Wang, Acta Mater. 51, 5131 (2003).

28. J. Liu, J. Chen, X. Yang, S. Ren, C. Wu, H. Xu, and J. Zou, Scr. Mater. 63, 1061 (2010).

29. G. Sha and A. Cerezo, Acta Mater. 52, 4503 (2004).

30. W. Shu, L. Hou, C. Zhang, F. Zhang, J. Liu, J. Liu, L. Zhuang, and J. Zhang, Mater. Sci. Eng. A 657, 269 (2016).

31. S. Ringer and K. Hono, Mater. Charact. 44, 101 (2000).

32. C. B. Fuller, M. W. Mahoney, M. Calabrese, and L. Micona, Mater. Sci. Eng. A 527, 2233 (2010).

33. R. A. Siddiqui, H. A. Abdullah, and K. R. Al-Belushi, J. Mater. Process. Technol. 102, 234 (2000).

34. J. J. Gracio, F. Barlat, E. F. Rauch, P. T. Jones, V. F. Neto, and A. B. Lopes, Int. J. Plast. 20, 427 (2004).

35. A. J. Kulkarni, K. Krishnamurthy, S. P. Deshmukh, and R. S. Mishra, J. Mater. Res. 19, 2765 (2004).

36. T.-F. Chung, Y.-L. Yang, B.-M. Huang, Z. Shi, J. Lin, T. Ohmura, and J.-R. Yang, Acta Mater. 149, 377 (2018).

37. J. C. Werenskiold, A. Deschamps, and Y. Bréchet, Mater. Sci. Eng. A 293, 267 (2000). 